\title{
PORQUE A PEDAGOGIA DE CÉLESTIN FREINET AINDA É ATUAL
}

Ivan FORTUNATO ${ }^{1}$

O ano de 2016 foi marcado pelo $50^{\circ}$ aniversário do falecimento de Célestin Freinet. Desde que ele se foi, a educação escolar mudou muito pouco, sendo possível inferir que o passado ainda é presente (FORTUNATO, 2016a). Há quase 100 anos, este educador já havia constatado que as práticas escolares não fazem sentido à vida dos educandos, bem como a rigidez dos currículos e as atividades repetitivas, com foco na memorização, não se inscrevem nas vidas dos educandos. Tais assertivas ainda são válidas. Aliás, ouso afirmar que, nestes últimos 50 anos, a escola parece até ter retrocedido, pois, na ausência de um dos grandes heróis da educação, ficou fácil resignar o trabalho transformador, retornando ao inercial tradicionalismo secular (FORTUNATO, 2016b). Tais constatações levam, em princípio, a um rol de lamentações.

Assim, lamento não ter conhecido Freinet em vida, senão por meio de seus esperançosos escritos. Lamento não ter estudado em uma instituição participante do seu Movimento da Escola Moderna. Lamento, enquanto professor, ceder às pressões burocráticas e ao sistema generalizante de avaliar, aprovar e reprovar os estudantes, controlar a frequência e exigir tarefas insignificantes.

Por outro lado, ao tomar contato com a vida e obra de Célestin Freinet, especialmente sua militância na escola da educação básica, suas batalhas vencidas, suas bandeiras de luta e suas técnicas (cf. LEGRAND, 2010), tornou-se possível divisar um caminho mais iluminado e mais fértil para educação. Dessa forma, longe dos queixumes sobre sua ausência em minha vida escolar, é preferível listar o que foi aprendido com este educador. Aliás, arrisco aqui anotar que se não fosse pelo contato com a pedagogia Freinet, provavelmente eu teria abandonado a carreira docente ou, pior, teria cedido à indiferença e à inércia da secular educação escolar, ou seja: ensinando/instruindo/doutrinando os estudantes, da mesma forma como sempre foi feito.

${ }^{1}$ Doutor em Geografia pela UNESP. Professor do Programa de Pós-Graduação em Ciências Humanas e Sociais-UFABC, do Programa de Pós-Graduação em Educação-UFSCar-Sorocaba e do IFSPItapetininga. Email: ivanfrt@yahoo.com.br. 
Nesse sentido, tenho orgulho de ter encontrado, ao acaso, um livro de Freinet (1975) e nele tido amparo para continuar lecionando. Suas técnicas me motivaram a trabalhar em prol de uma educação mais livre e a pleitear novas formas de educar (FORTUNATO, 2013). Assim, me orgulho de, hoje, poder conduzir atividades de acordo com interesse de cada aluno - mínimo que seja - permitindo que cada um tire algum proveito particular das aulas obrigatórias. Também me orgulho de batalhar, dia após dia, para lecionar sem o cabresto curricular e a rigidez dos horários estanques. Além disso, compreendi com Freinet que a vida acontece fora dos muros escolares. E isso me fez levar os estudantes matriculados em minhas disciplinas para dentro de escolas e instituições de ensino não-formal. O objetivo disto é que a gente possa, pela experiência direta com jovens e crianças, aprender e ensinar cooperativamente.

Assim, enquanto gestava e buscava amadurecer essas ideias pedagógicas, fui me debruçando nas obras escritas por Freinet, encontrando respaldo naqueles que ele mesmo anotou como referências, principalmente Dewey e Decroly. Mas, como bem anotou Elise Freinet (1979), seu marido acabou por superar os renomados pensadores, justamente porque ele não trocou os desafios de estar na escola e de ensinar as crianças a reconhecerem a si mesmas, reconhecerem seus pares e o mundo que as cercam, pela segurança dos muros universitários. Isso porque Freinet entendia que a educação somente poderia ser transformadora se fosse feita na prática, no contato direto com quem tem o direito (e o desejo) de aprender.

Descobri, então, que sua proposta pedagógica ainda persiste pelo mundo nas diversas Redes Freinet e Movimentos de Escola Moderna. Isso quer dizer que, ao redor do planeta, coletivos de educadores se reúnem para recuperar seus ensinamentos e demonstrar que seus pressupostos ainda são válidos, e se fazem presentes (ou necessários) no cotidiano escolar. No Brasil, por exemplo, temos a Rede de Educadores e Pesquisadores da Educação Freinet (REPEF), promovendo encontros anuais para partilha de práticas e saberes pedagógicos. Por isso é possível - e necessário - falar sobre a atualidade da pedagogia Freinet.

Essa ideia não é nova, tendo sido apresentada por Imbernon (2010) quando publicou a obra "Las invariantes pedagógicas y la pedagogia Freinet cincuenta años después". Nela, o autor recuperou memórias de como conheceu Freinet (pelos seus escritos), e de como foi por ele influenciado a pensar em maneiras mais práticas de ensinar, bem como da importância de se exercer a profissão docente de forma progressista. Muito me identifico com esse livro, pois, assim como Imbernon (2010), 
acredito que a pedagogia de Célestin Freinet é uma das mais importantes para a escola; tomo-a como uma prática atual e, do mesmo modo, tomei conhecimento de suas técnicas e teorias de forma "clandestina", ou seja, fora do currículo universitário que se pressupunha o ideal para formação de professores.

As semelhanças não param por aí: nós reconhecemos a validade e a perenidade de suas "invariantes pedagógicas", que são afirmações contundentes sobre educação, válidas em qualquer contexto. Por exemplo, Freinet percebeu que a natureza da criança não difere da natureza do adulto, ou seja, são seres humanos que aprendem de maneira muito semelhante. Outras invariantes dizem respeito às técnicas de ensino e a necessidade de superação da velha escola: ninguém - seja criança, seja adulto - gosta de tarefas impostas e sem sentido, mas todos têm prazer em realizar atividades que consideram importantes para sua própria vida (FORTUNATO; CUNHA; TEMPLE, 2016). Essas invariantes pedagógicas podem ser entendidas como o último esforço de Freinet para a educação escolar, pois ele as escreveu praticamente no final de sua vida. As invariantes, junto com o que ele chamou de "guia prático" para os trabalhos com a escola, foram publicados em seu último livro, sendo esta uma obra póstuma (FREINET, 1969).

Outra similaridade que há na relação de Imbernon com Freinet com minha própria relação com Freinet é que ambos nos sentimos, de certa forma, em dívida com o educador francês. Mesmo que sua influência em minha prática e crenças pedagógicas seja continuamente expressada, parece que estou longe de corresponder ao seu legado. Dessa forma, assim como Imbernon, também tenho buscado formas de ressaltar sua singular importância para a escola.

Com isso, foi pensando em apoucar essa dívida com Freinet que promovi este "encontro" entre professores e pesquisadores que veem, na sua pedagogia, uma forma ainda muito viva de se educar. Os textos reunidos neste dossiê foram produzidos no Brasil, na Espanha, no Portugal e no Canadá, com o propósito de relembrar a batalha de Freinet pela educação escolar. Servem, ainda para agradecer suas lições, bem como para disseminar suas palavras que inspiram a almejar nada além de um ensino menos frustrante, e um aprendizado mais profícuo. 


\section{Referências}

FREINET, C. As técnicas de Freinet da Escola Moderna. 4a. ed. Lisboa, Portugal: Editorial Estampa, 1975.

FREINET, C. Pour l'école du peuple. Paris: Maspero, 1969.

FREINET, É. O itinerário de Célestin Freinet: a livre expressão na pedagogia Freinet. Rio de Janeiro, Brasil, Livraria Francisco Alves Editora S.A., 1979.

FORTUNATO, I. Aprendendo com Célestin Freinet: o passado ainda é presente. Tendência Pedagógicas, Madrid, v. 27, n. 1, p. 251-258, $2016 \mathrm{a}$.

FORTUNATO, I. 50 Anos sem Célestin Freinet, 500 Anos de Retrocesso das Práticas Escolares. Journal for Educators, Teachers and Trainers, Granada, v. 7, p. 174-181, $2016 b$.

FORTUNATO, I.; CUNHA, C. R.; TEMPLE, C. Célestin Freinet's pedagogical invariants: a pathway to free and collaborative school education. Quaderni di didattica della scrittura, Barletta, v. 26, p. 44-51, 2016.

FORTUNATO, I. Algumas ideias de Celestin Freinet para motivar a docência. Direcional Educador (Impresso), São Paulo, v. 105, p. 34-36, 2013.

IMBERNON, F. Las invariantes pedagógicas y la pedagogia Freinet cincuenta años después. Barcelona: Graó, 2010.

LEGRAND, Louis. Célestin Freinet. Trad. José Gabriel Perissé. Recife, Fundação Joaquim Nabuco, Editora Massangana, 2010.

\section{Como referenciar este artigo}

FORTUNATO, Ivan. Porque a pedagogia de Célestin Freinet ainda é atual. Revista Ibero-Americana de Estudos em Educação, Araraquara, v. 12, n. esp. 1, p.542-545, 2017. Disponível em: <http://dx.doi.org/10.21723/riaee.v12.n.esp.1.2017.9658>. EISSN: 1982-5587. 